http://nv.nltu.edu.ua

https://doi.org/10.15421/40280418

Article received 19.04.2018 p.

Article accepted 26.04.2018 p.

\title{
МАРКЕТИНГОВИЙ ПІДХІД ДО ВИЗНАЧЕННЯ КАТЕГОРІЇ "ТУРИСТИЧНИЙ ПРОДУКТ"
}

\begin{abstract}
Розглянуто основні підходи до трактування суті поняття "туристичний продукт". Це зробили вітчизняні та світові дослідники з цієї проблематики. Особливу увагу приділено аналізу поняття "туристичний продукт" із позиції маркетингу. Наведено власне визначення категорії "туристичний продукт" із використанням маркетингового підходу. Також виявлено чинники впливу на туристичний продукт та формування попиту на нього. Висвітлено види туристичного продукту, проаналізовано його елементи й охарактеризовано особливості маркетингового складника туристичного продукту сучасного ринку. З'ясовано, що туристичний продукт із погляду туриста, а не суб'єкта туристичної галузі, бере свій початок із первинного джерела інформації (де турист почув про туристичний продукт) і триває довше, аніж закінчення самого туру (через отримані емоції від подорожі). Зазначено, що значна частка в структурі туристичного продукту належить саме емоційній складовій. Проаналізовано фази життєвого циклу туристичного продукту та виявлено, що використання такого маркетингового інструменту, як просування продукту, прямо пропорційно впливатиме як на попит, так і на продовження життєвого циклу туристичного продукту загалом. Запропоновано значне використання засобів просування туристичного продукту на ринку для ширшого охоплення цільової аудиторії та створення належних каналів комунікації із споживачем.
\end{abstract}

Ключові слова: туристичний продукт; туристичний пакет; туристичні послуги; дестинація; тур; маркетинг.

Вступ. Відповідно до концепції соціального маркетингу Котлера, ключ до досягнення цілей організації це вивчення потреб та побажань цільових ринків і забезпечення бажаного рівня їх задоволення ефективнішим за конкурентів способом, тоді як рівень добробуту споживача та суспільства зберігається або й зростає. Науковець інтерпретує саме поняття продукту досить широко, визначивши його не тільки як матеріальний предмет, запропонований на ринку, але й включає у нього все необхідне для задоволення потреб окремих малих та великих соціальних груп (Bondarenko, 2011; Butko, 2008).

Основною вимогою концепції сучасного маркетингу $\epsilon$ аналіз туристичного продукту крізь призму потреб туристів та його переваг, адже за Ф. Котлером продукт це все те, що може бути запропоновано споживачеві для задоволення його потреб. Отже, основний критерій будь-якого продукту $є$ не тільки його фізичною сутністю, чи це товар, чи послуга, а те, чи відповідає він потребам споживача (Butko, 2008; Hrabovenska, 2013).

Завдяки сутності феномена туризму та його складній структурі, що склалася нині, поняття, що визначає продукт у туристичній галузі, $є$ складнішим, ніж в інших сферах. Первинна проблема полягає в тому, що різні підприємства обслуговують туристичний ринок і вони бачать цей продукт по-різному (Marczak \& Borzyszkowski, 2017).

Аналіз останніх досліджень та публікацій. Поняття туристичного продукту досліджено у працях ба- гатьох українських науковців. Науковий інтерес становлять праці Л. Г. Агафонової, І. Ю. Афанасьєвої, Л. П. Дядечко, В. Ф. Кифяка, О. О. Любіцевої, Т. І. Ткаченко, Л. М. Устименко, І. М. Школи, В. К. Кіптенко та ін. Важливе значення мають праці іноземних вчених - Ф. Котлера, М. Портера, Н. Тейлора, Дж. Холловея, І. I. Бутко та ін. Велику частку в дослідженні становлять щорічні звіти Світової туристичної організації UNWTO і Світового економічного форуму. У цих працях висвітлено аспекти формування, функціонування та розвитку туристичних послуг в Україні (Hrabovenska, 2013; Kotler, 2007).

Викладення основного матеріалу дослідження. У Законі України "Про туризм" зазначено таке: Туристичний продукт - це попередньо розроблений комплекс туристичних послуг, який поєднує не менше ніж дві такі послуги, що реалізується або пропонується для реалізації за визначеною ціною, до складу якого входять послуги перевезення, послуги розміщення та інші туристичні послуги, не пов'язані з перевезенням і розміщенням (послуги з організації відвідувань об'єктів культури, відпочинку та розваг, реалізації сувенірної продукції тощо) (Zakon Ukrainy, 1995). А Всесвітня туристична організація наголошує на тому, що туризм - це не тільки економічне, але одночасно соціальне, культурне, екологічне і політичне явище (Kariahin et al., 2009).

Отже, згідно із запропонованим визначенням можемо вважати, що на туристичний продукт мають вплив такі маркетингові чинники: політичні, економічні, геог-

Інформація про авторів:

Пушек Наталія Мирославівна, аспірант, кафедра маркетингу. Email: pushuni4ka@gmail.com

Гнилякевич-Проць Ірина Зіновіївна, канд. екон. наук, доцент, кафедра маркетингу. Email: Konkurs.Inu@gmail.com

Цитування за ДСту: Пушек Н. М., Гнилякевич-Проць І. З. Маркетинговий підхід до визначення категорії "туристичний продукт". Науковий вісник НЛТУ України. Серія Економічна. 2018, т. 28, № 4. С. 97-101

Citation APA: Pushek, N. M., \& Hnylyakevych-Prots, I. Z. (2018). Marketing Approach to the Definition of the Category "Tourist Product". Scientific Bulletin of UNFU, 28(4), 97-101. https://doi.org/10.15421/40280418 
рафічні, культурні, соціальні, екологічні та ін. Тобто для того, щоб туристичний маркетинг докладніше відображав інтереси як туристичних компаній, так і споживачів туристичного продукту, необхідно враховувати всі перераховані вище чинники (Kotler, 2007; Liubitseva, 2005; Hrytsiuk \& Grytsyuk, 2016).

Посилення конкуренції на туристичному ринку зменшує кількість основних гравців ринку, зокрема, туроператорів, які намагаються сформувати комплексний пакет туристичних продуктів, що володіє більшою споживчою цінністю, аніж кожен із туристичних продуктів взятий окремо, адже сфера туризму надає послуги, які задовольняють попит туристів. Відповідно, комплексний підхід у формуванні пакету туристичних продуктів дає змогу виокремити з-поміж них основні складові туристичного продукту (номер у готелі, трансфер) та другорядні (басейн, екскурсії).

На основі аналізу праць українських дослідників, таких як О. Любіцева, В. Кіптенко, під туристичним продуктом розуміємо комплекс товарів і послуг, матеріальних і нематеріальних благ та ресурсів, призначених для туристичного споживання, що реалізуються на ринку туристичних послуг (Liubitseva, 2005; Malska \& Antoniuk, 2008). Тобто - це сукупність речових (предмети споживання), неречових (послуги) споживчих вартостей, необхідних для повного задоволення потреб туристів, що виникають під час їхньої подорожі (поїздки) і викликані саме цією подорожжю. Він є здебільшого вузькоспеціалізованим, має складну, динамічну структуру, пристосовану до зміни попиту, і здатен забезпечити задоволення різноманітних потреб людини, котра подорожує (Malska \& Antoniuk, 2008; World \& Tourism, 2012).

Також варто зазначити, що поняття туристичного продукту на макро- та мікрорівні відрізнятиметься. На макрорівні туристичний продукт - це сукупність товарів і послуг, що створює туристичну поїздку (тур) або має 3 нею прямий зв'язок і підлягає оплаті з боку туриста. У сукупності туристичних послуг можна виділити посередницькі, екскурсійні, комунальні, перекладацькі, готельні, транспортні, побутові послуги. Туристу запропоновано комплексний набір послуг. Туристичний продукт на мікрорівні - це послуги, що надає будь-який окремий суб'єкт туристичної індустрії (готель, туроператор, авіакомпанія тощо) (Kiptenko, 2010).

Для чіткого розуміння поняття туристичний продукт, можна виділити кілька особливостей, що виокремлюють туристичний продукт 3-поміж інших.

По-перше, оскільки туристичний продукт на $80 \%$ складається із послуг, то йому притаманні певні ознаки, що характеризують послуги. Наприклад, його практично не можливо осягнути до купівлі, не можна відчути на дотик, приміряти, спробувати на смак тощо (Marczak \& Borzyszkowski, 2017; World \& Tourism, 2012).

По-друге, це неоднорідність туристичного продукту - один і той самий продукт може бути абсолютно різним для двох туристів, адже на нього може вплинути погода, сервіс тієї чи іншої зміни персоналу (один і той самий тур відпочинку на узбережжі моря, проданий двом різним туристам, одному з яких поталанило потрапити у пік спеки, а іншому - у сезон дощів, це два зовсім різні туристичні продукти). Купуючи тур, турист ніколи не знає, що купує. I туроператор теж не може гарантувати певних умов.
По-третє, туристичному продукту притаманна недовговічність - дуже часто туристичний продукт характеризує сезонність, що передбачає гнучку цінову політику.

По-четверте, туристичний продукт - це комплексне поняття, адже враження від туристичного продукту турист отримує, починаючи від спілкування з агентом туроператора і закінчуючи прощанням із борт-провідником, що супроводжує туриста в дорозі назад.

Вітчизняні науковці виділяють три основні складники туристичного продукту, якими він може бути представлений на ринку (Kiptenko, 2010):

1) тур (комплексна туристична послуга) здійснюється відповідно до програми туристичної подорожі, котру пропонують фірми, туроператори (організатори), його можна продати споживачеві для особистого користування (вроздріб), а також гуртовим покупцям (фірмампосередникам, турагентствам) для отримання економічної вигоди;

2) окремі туристичні послуги, до яких можна зарахувати транспортні послуги, послуги з розміщення, оформлення закордонних паспортів, страховку, екскурсійну програму, прокат автомобіля тощо;

3) товари туристичного призначення, зокрема, різні інформаційні матеріали (каталоги, довідники, карти, словники, путівники тощо), необхідні туристу і мандрівнику в країні перебування.

Український економіст, учений П. М. Шеремета виділяє два складники туристичного продукту:

1. Hardware - інфраструктурний комплекс, що надає послуги туристу (готель, ресторан, сувенірна крамниця, екскурсійний трамвай тощо);

2. Software - емоційний складник, адже, як відомо, у нашу епоху основна потреба туриста не в матеріальних благах, а в емоціях, які він отримує від вивчення традицій корінного населення, його історичних пам'яток, чи природних принад.

На думку вчених із Мічиганського університету, туристичний продукт - це продукти, які складаються 3 об'єктів та визначних пам'яток, транспортування, проживання та розваг, де кожен елемент туристичного продукту готують окремі компанії і пропонують споживачам (туристам); комплекс елементів, які є невід'ємною частиною подорожі туриста та задовольняють потреби туриста від виїзду з місця проживання до місця призначення та назад до місця проживання. Відтак, один із перших дослідників галузі туризму у світі А. Дж. Буркарт визначає шість складників, що утворюють туристичний продукт (Burkat, 2013):

1. Об'єкти та визначні пам'ятки.

2. Послуги турагентів та туроператорів.

3. Транспортні послуги.

4. Послуги з проживання, харчування, відпочинку та розваг.

5. Сувенірні послуги (сувенірні товари).

6. Підтримка та регулювання бізнес-послуг органами державного самоврядування.

Очевидно, що у цьому випадку складники туристичного продукту визначено з позиції його формування. У цей перелік внесено всі фізичні прояви туристичного продукту, однак опущено емоційний складник.

Польські дослідники пропонують таку класифікацію туристичного продукту (Marczak \& Borzyszkowski, 2017): 
1. Товар - всі матеріальні речі. Цей вид туристичного продукту може бути самодостатнім, але зазвичай це тільки доповнювач до інших продуктів. До них належать туристичні гіди, карти, обладнання, необхідне під час подорожі (весла, сувеніри) тощо.

2. Послуга - сервіс, що передбачає комплекс послуг (транспорт, проживання, харчування, послуги гіда).

3. Систематична подія - це повторювана подія, що відбувається у визначеному місці у певний визначений час, яка передбачає велике нагромадження людей та конкретну тематику. Така подія повинна бути особливою та винятковою для споживача (Фестиваль слов'ян та вікінгів, Октоберфест, Міжнародний джазовий фестиваль "Золотий грат").

4. Ситуативна подія - це певний захід, організований на замовлення клієнта за участі туристичних агентів (корпоративні поїздки, свята, мітинги).

5. Об'єкт - це головна визначна пам'ятка, яка може супроводжуватися додатковими послугами або іншими продуктами, що має точковий характер (Дуб Бартек або Тевтонський замок у Мальборку).

6. Дестинація - визначений маршрут, що складається з багатьох місць або об'єктів, які пов'язані однією загальною ідеєю. За маршрутом можна зазвичай знайти різноманітну туристичну інфраструктуру ("Орлині стежки", "Пішохідні стежки", "Коперник Трейл").

7. Територія - визначена географічна зона, в якій є туристичні визначні пам'ятки, та надаються послуги.

У роботах дослідників галузі туризму із В'єтнамського університету туристичний продукт асоціюють із поняттям туристичний пакет (комплекс послуг, що надають під час подорожі за індивідуальним або груповим варіантом, який пропонують для широкого продажу споживачам, до якого, окрім транспорту, входять послуги розміщення, послуги гіда, харчування та інші види обслуговування тощо (Pravyk, 2008)) для задоволення очікувань потенційних туристів. У країнах Сходу також дотримуються думки, що туристичний продукт, як і будь-який інший продукт, проходить через усі етапи життєвого циклу товару, тобто туристичний продукт виходить на ринок, зростає до зрілості, а потім поступово спадає. Якщо спад виявлено вчасно, то запобігти різкому зниженню можна за допомогою зменшення цін, диференціації продукту, основним засобом якої стає сервісна диференціація; просування з метою збільшення прихильності інтенсивних споживачів (споживачі, що регулярно користуються певними послугами, чи купують той чи інший товар); додаткової ін'єкції реклами, при цьому наголошуючи на перевагах продукту (Nguyen, 2015).

Варто зазначити, що життєвий цикл у туристичного продукту як окремого підприємства туристичної індустрії, так і туристичного продукту в межах певної території характеризується певними фазами продуктової політики, які є схожими з фазами життєвого циклу продукту на ринку товарів і послуг, а саме: фаза впровадження, розвитку, зрілості та фаза старіння.

Розглянемо особливості фаз життєвого циклу на прикладі туристичного продукту, який передбачає відпочинок у ще неосвоєній туристичній місцевості (Liubitseva, 2005; Myronov, 2010; Pravyk, 2008; Burkat, 2013).

У фазі впровадження перевагами такого туристичного продукту є новизна вражень, але відсутність мережі додаткових послуг. Такий продукт призначено для людей, яким набридли шумні переповнені курорти і які не примхливі до можливих незручностей.

3 часом туристична місцевість починає наповнюватись об'єктами інфраструктури - ресторани та інші розважальні й культурні заклади, що сприяють і потребують удосконалення умов проживання, якості харчування. Йдеться про фазу розвитку.

Рекламні кампанії, приватна інформація сприяють припливу щораз більшої кількості туристів. Потенційні можливості туристичної місцевості використовують максимально, тому пов'язані з нею туристичні продукти переходять у фазу зрілості. Органи місцевої влади починають вдаватися до планування, координації та контролю туристичного руху, піддають стандартизації туристичні послуги.

Головною передумовою фази старіння є зменшення туристичних прибутків. Подальша пропозиція туристичного продукту починає приносити споживачам більше роздратування, ніж користі. Це потребує повного оновлення структури туристичного продукту.

Перебіг зазначених фаз життєвого циклу туристичного продукту залежить від таких чинників, як: природні особливості території; можливості залучення капіталів; структура туристичного руху; мода тощо.

На життєвий цикл туристичного продукту також опосередковано впливають такі чинники, як: політична нестабільність в країні, забруднення навколишнього середовища, інвестиційна політика держави тощо. Можливим $є$ також перебіг життєвого циклу туристичного продукту, коли відсутніми є окремі фази (Myronov, 2010). Наприклад, Діснейленд, де після впровадження, об'єкт дуже різко набув популярності і потрапив у фазу зрілості, пропустивши фазу зростання.

Однак варто зазначити, що маркетингові інструменти вагомо впливають на формування попиту на туристичний продукт та, на його життєві цикли відповідно. Зокрема, 3-поміж інших варто виокремити - просування (налагодження зв'язків із реальними та потенційними споживачами туристичних послуг для їх інформування про пропоновані туристичні продукти і спонукання до їх купівлі).

Подібні зв'язки реалізуються через такі канали просування, як: реклама в засобах масової інформації та інших визнаних рекламо носіях; стимулювання продажу; прямий продаж (прямий маркетинг); зв'язки з громадськістю (PR). У процесі формування ефективних каналів комунікації із споживачами 3 метою просування туристичного продукту є виконання основних етапів роботи, a саме: планування просування турпродукту на ринку; вибір каналів просування і рекламоносіїв; складання рекламного звернення; виконання й оцінка ефективності реклами.

Планування просування туристичного продукту на ринку охоплює: дослідження ринку, окреслення цілей, формування і розподіл бюджету. Дослідження ринку (збутової території), споживача і туристичного продукту -3 вихідною точкою планування. Збутовою територією вважають цю територію, на якій необхідно поширити рекламне звернення і здійснити інші заходи з просування турпродукту. Знання особливостей споживача допомагає вибрати конкретні канали і засоби просування, які зможуть донести до нього найповнішу інформацію про турпродукт. Аналіз туристичного продукту необхідний для того, щоб у рекламному зверненні під- 
креслити його унікальні властивості. Загальною метою просування турпродукту є підвищення його популярності. Однак більш конкретною метою суб'єкта туристичного ринку буде донесення інформації про туристичний продукт до кожного цільового ринку і цільового сегмента (Pravyk, 2008).

Висновки. Підсумовуючи, варто зазначити, що туристичний продукт - це комплекс товарів і послуг, які користуються попитом у туриста до, під час та після його подорожі, адже він починається із сервісу туроператора та закінчується емоціями, які турист отримує від подорожі. Туристичному продукту, 3 погляду маркетингу, притаманно чимало ознак як і будь-якому іншому продукту у вигляді товару чи послуги, зокрема, це життєвий цикл туристичного продукту, він як і більшість товарів і послуг після потрапляння на ринок переживає фазу розвитку, зрілості та старіння. Найбільш істотною відмінністю туристичного продукту є те, що його розглядають як комплекс товарів і послуг, а не як окремий вид послуги чи окремий товар. Політичний та економічний стан, географічне положення, соціокультурний розвиток населення, екологічний стан місцевості - це основні чинники, які впливають як на формування самого туристичного продукту, так і на його попит. Однак варто зазначити, що не менш важливий вплив, особливо на туристичний продукт певної території, має такий чинник, як промоція, адже здебільшого саме вона має вплив на кінцеве рішення туриста. Раціональне розуміння поняття туристичний продукт дасть змогу визначити саме ті інструменти маркетингу, використання яких матиме позитивний вплив на популяризацію українського туристичного продукту на внутрішньому та зовнішніх ринках.

\section{Перелік використаних джерел}

Bondarenko, M. P. (2011). Turystychnyi sektor ekonomiky Ukrainy: realii ta perspektyvy. Ekonomika i prohnozuvannia: naukovyi zhur- nal, 1, 104-119. In-t ekon. ta prohnozuv. NAN Ukrainy. [In Ukrainian].

Burkat, A. (2013). Tourism Product Definition. Retrieved from: http://lokatourconsultant.blogspot.com/2013/04/tourism-productdefinition.html

Butko, I. I. (2008). Turisticheskii biznes: osnovy organizatcii. Vol. 2. Rostov n/D: Feniks. 384 p. [In Russian].

Hrabovenska, S. P. (2013). Analiz i struktura rynku turystychnykh posluh Ukrainy. Naukovyi visnyk Poltavskoho universytetu ekonomiky i torhivli, 1(56), 123-128. 226 p. [In Ukrainian].

Hrytsiuk, Yu. I., \& Grytsyuk, M. Yu. (2016). Modeliuvannia stratehii povedinky konkurentnykh firm na rynku nadannia turystychnykh posluh. Bulletin of the National University "Lviv Polytechnic". Series of Information Systems and Networks, 854, 50-62. Lviv: Vyd-vo NU "Lvivska poli-tekhnika". [In Ukrainian].

Kariahin, Yu. O., Tymoshenko, Z. I., Demura, T. O., \& Munin, H. B. (2009). Marketynh turproduktu: pidruchnyk. Kyiv: Kondor. 3 p. [In Ukrainian].

Kiptenko, V. K. (2010). Menedzhment turyzmu: pidruchnyk, (pp. 5770). Kyiv: Znannia. 230 p. [In Ukrainian].

Kotler, F. (2007). Osnovy marketynhu: korotkyi kurs. Kyiv: Vyd. dim "Viliams". 647 p. [In Ukrainian].

Liubitseva, O. O. (2005). Rynok turystychnykh posluh (heoprostorovi aspekty). (3rd ed.). Kyiv: Alterpres. 436 p. [In Ukrainian].

Malska, M. P., \& Antoniuk, N. V. (2008). Mizhnarodnyi turyzm i sfera posluh: pidruchnyk. Kyiv. 661 p. Retrieved from: http://pid ruch niki.com/17481012/turizm/prosuvannya_turistichnogo_produktu rinku. [In Ukrainian].

Marczak, Mirosław \& Borzyszkowski, Jacek. (2017). Region (obszar) jako produkt turystyczny. Warshaw. $260 \mathrm{p}$.

Myronov, Yu. B. (2010). Marketynh v turyzmi: opornyi konspekt lektsii, (pp. 50-54). Kyiv: Drohobych. 160 p. [In Ukrainian].

Nguyen Cong Hoan. (2015). Tourism Destination Products Management - Case Studies of Phu Quoc Island Kien Giang Province, Vietnam by 2020. Universal Journal of Management, 3(12), 509-513.

Pravyk, Yu. M. (2008). Marketynh turyzmu: pidruchnyk. Kyiv: Znannia. 303 p. [In Ukrainian].

World Travel \& Tourism Council. (2012). Travel \& Tourism Economic Impact 2012 Ukraine. London: [s. 1.]. 24 p.

Zakon Ukrainy. (1995). Pro turyzm. Retrieved from: http://zakon2.rada.gov.ua/laws/show/324/95-вp. [In Ukrainian].

Н. М. Пушек, И. З. Гнилякевич-Проць

Львовский национальный университет им. Ивана Франко, г. Львов, Украина

\section{МАРКЕТИНГОВЫЙ ПОДХОД К ОПРЕДЕЛЕНИЮ КАТЕГОРИИ "ТУРИСТИЧЕСКИЙ ПРОДУКТ"}

Рассмотрены основные подходы к трактовке сути понятия "туристический продукт" отечественными и мировыми исследователями данной проблематики. Особое внимание уделено анализу понятия "туристический продукт" с позиции маркетинга. С использованием маркетингового подхода предложено собственное определение категории "туристический продукт". Также выявлены факторы влияния на туристический продукт и формирования спроса на него. Проанализированы виды туристического продукта, его элементы и охарактеризованы особенности маркетинговой составляющей туристического продукта современного рынка. Указано, что туристический продукт, с точки зрения туриста, берет свое начало с первичного источника информации (где турист услышал о туристическом продукте) и длится дольше, нежели окончание самого тура (из-за полученных эмоций от путешествия). Отмечено, что значительное долевое участие в структуре туристического продукта принадлежит именно эмоциональной составляющей. Проанализированы фазы жизненного цикла туристического продукта, и обнаружено, что использование такого маркетингового инструмента, как продвижение продукта, осуществляет прямо пропорциональное влияние как на спрос, так и на продление жизненного цикла туристического продукта в целом. Предложено широкое использование средств продвижения туристического продукта на рынке с целью более широкого охвата целевой аудитории и создания каналов коммуникации с потребителем.

Ключевые слова: туристический продукт; туристический пакет; туристические услуги; дестинации; тур; маркетинг.

N. M. Pushek, I. Z. Hnylyakevych-Prots

Ivan Franko National University of Lviv, Lviv, Ukraine

\section{MARKETING APPROACH TO THE DEFINITION OF THE CATEGORY "TOURIST PRODUCT"}

In recent years, the role of tourism has been growing at a rapid pace in any economic system, and marketing mix $4 p s$ model is an essential component of any economic activity including tourism industry. In this study we use empirical method, method of economic analysis, deductive and inductive methods. The principles of marketing relationship demonstrate a close tie between the customer's requirements and product offers, as well as the results of economic activity depend on correspondence to these requirements. Therefore, in this paper we investigate the concept of tourist product from the marketing position. We considered the basic approaches to the interpretation of the concept of "tourist product" by domestic and international researchers of this problem, and analysed 
different types of tourist product classification. The structure and features of tourist product were also analysed in this study. We revealed marketing factors that influence tourist product demand, such as political economic and ecological situation, geographical location, and cultural and social factors. Therefore, tourist product is not only a complex of goods and services that form the tourist trip and are paid by the tourist, such as transport and transfer, hotels and restaurants, sightseeing, attractions and souvenirs. Tourist product structure also includes one more very important component. It is an emotional component. As a result, from the tourist point of view the tourist product starts from the source where tourist takes information about the tourist product and it continues longer than a trip, because of the emotions the tourist got. Moreover, we considered the phase of the tourist product life cycle, such as the phase of implementation, growth, maturity and decline. We revealed that using of such marketing tool as product promotion has a direct proportional effect on both demand and prolonging of the tourist product life cycle. Widespread using of the means of promoting a tourist product on the market is proposed in order to expand the reach of target audience and create appropriate communication channels with the consumers. In the future we are going to reveal the most effective marketing tool in tourist industry.

Keywords: tourist product; tourist package; tourist services; destination; tour; marketing. 